\title{
Effectiveness of Performance of Prosecutor's Office in Preventing Corruption Crime after the Team's Disbandment
}

\author{
Joko Kris Sriyanto *) and Bambang Tri Bawono **)
}

*) Student of Master of Law, Faculty of Law, Universitas Islam Sultan Agung Semarang, E-mail: joko.kris.sriyanto85@gmail.com

**) Lecturer of Master of Law, Faculty of Law, Universitas Islam Sultan Agung Semarang.

\begin{abstract}
.
The objectives of this study are: 1. To find out and analyze the effectiveness of performance of Grobogan District Attorney in the context of preventing criminal acts of corruption after the dissolution of Regional Government and Regional Development Guards and Security Team (TP4D) in the construction of legal system. 2. To find out and analyze the obstacles faced by the Grobogan District Attorney in the context of preventing criminal acts of corruption after the dissolution of Regional Government and Regional Development Guards and Security Team (TP4D) and their solutions. The research method used is juridical sociology, which is an approach that studies social phenomena in society with legal aspects. Based on the research, it is concluded that as the implementation of duties of Guards Team, Government Security and Regional Development (TP4D), the Grobogan District Prosecutor's Office remains professional in carrying out its duties in the context of preventing criminal acts of corruption after the dissolution of guard and security team for government and regional development (TP4D) in the construction of a legal system that is right. in a period of 3 (three) years, starting in 2016, 2017, 2018 and 2019, the Team of Guards, Safeguards for Government and Regional Development (TP4D) of Grobogan District Prosecutor's Office has handled corruption crimes, showing an achievement from one of roles. The Attorney General's Office in optimizing the prevention of criminal acts of corruption through the Regional Government and Development Guard and Security Team (TP4D).

Keywords: Effectiveness; Performance of Attorney General's Office; Prevention of Corruption Crime.
\end{abstract}

\section{Introduction}

Law enforcement in the context of eradicating criminal acts of corruption is not only needed by means of laws and regulations, but also requires instruments for the activation of law enforcement institutions, such as the Indonesian National Police, the Republic of Indonesia Attorney General's Office, judiciary bodies and prisons, in the case of criminal acts of corruption, even though the Commission Corruption Eradication (KPK). ${ }^{1}$ The Grobogan District Attorney, which is part of structure of Republic of Indonesia Prosecutor's Office, which carries out the authority of Republic of Indonesia Prosecutor in the jurisdiction of Grobogan Regency, Central Java Province, is certain to carry out the work program of

\footnotetext{
1 Yosy Budi Santoso and, Umar Ma"ruf. Kebijakan Pembuktian Dan Penuntutan Oleh Jaksa Penuntut Umum Dalam Pemberantasan Tindak Pidana Korupsi. Jurnal Hukum Khaira Ummah Vol. 12. No. 2 June 2017. p.360.
} 
Indonesian Prosecutor's Office in the context of law enforcement as well as optimizing the role and functions of Prosecutor's Office in the Grobogan Regency area. for the prevention of criminal acts of corruption by establishing Team of Guards, Government Security and Regional Development (TP4D) in the jurisdiction of Grobogan Regency with the organizational structure of Kasi Intel Kejari Grobogan as Chair, Kasi Datun Kejari Grobogan as Deputy Chair, and Kasi Pidsus Kejari Grobogan as Secretary, and Functional Prosecutors and staff at Grobogan Prosecutor's Office as members.

The Grobogan District Prosecutor's Office from 2017 to 2019 has done this escorting, securing, and assisting various development activities in each Regional Apparatus Organization (OPD) within the Grobogan Regency Government, it was recorded that there were 350 development activities accompanied by the TP4D Kejari Grobogan Team in 2017, in 2018 as many as 81 development activities, in in 2019, there were 54 development activities. ${ }^{2}$ The Grobogan District Prosecutor's Office in its efforts as law enforcers has made efforts since the formation of Regional Government and Regional Development Guards and Security Team (TP4) as a form of corruption prevention, data shows from 2016 to 2019 (during the assistance of TP4D Team) criminal acts of corruption shows a decrease in numbers, this can be seen in the data on corruption crimes handled by the Grobogan District Prosecutor's Office.

After the dissolution of TP4D Team, the Grobogan District Prosecutor's Office in addition to enforcing the law will also optimize its role and function in the Grobogan Regency area to prevent criminal acts of corruption, function the duties of Civil and State Administration and the Intelligence sector to carry out activities. in order to make efforts to prevent criminal acts of corruption in Grobogan Regency, but there are interesting things that make the author conduct research, especially how the effectiveness of Grobogan District Prosecutor's performance after the dissolution of Regional Government and Regional Development Guard and Security Team, especially in terms of preventing corruption in the Grobogan Regency area, considering the data shows that in 2020 there are findings of Grobogan District Attorney corruption, namely during the year the Grobogan District Attorney has conducted 2 (two) investigations, and 1 (one) has been upgraded to the Investigation stage, then also added 1 (one) corruption case from the Grobogan Police, of course, the question arises whether the efforts to prevent corruption in the Grobogan Regency area were not or not effectively carried out by the Grobogan District Prosecutor's Office after the dissolution of Regional Government and Regional Development Guards and Security Team, or TP4D was the only effort to prevent corruption.

\section{Research Methods}

This study uses a sociological juridical approach. The sociological juridical approach is an approach that studies social phenomena in society with legal aspects. ${ }^{3}$ While sociological research, which examines how the reactions and

\footnotetext{
2 TP4D data base for the Grobogan District Prosecutor's Office.

${ }^{3}$ Much Arif Saiful Anam. Jurnal Pendidikan Agama Islam. Volume 3 Nomor 2, 2015. p.386-392.
} 
interactions that occur when the norm system works in society. ${ }^{4}$ The task of researcher is to examine what is behind the appearance of application of laws and regulations. The type/specification of descriptive analytical research is research that describes or describes reality, providing data as accurately as possible about humans, circumstances, or other symptoms. ${ }^{5}$

The type/specification of this research used is descriptive analytical, which describes the applicable laws and regulations in relation to legal theories, ${ }^{6}$ Types of data in this study include primary data and secondary data. This study focuses on primary data, while secondary data is more of a supporting character. ${ }^{7}$ Data collection methods, including literature study, observation, interviews.

The data analysis method uses qualitative analysis, which means that the results of this study are described in the form of explanations and descriptions of sentences that are easy to read and understand to be interpreted and conclusions drawn about The Effectiveness of Performance of Attorney General's Office in Preventing Corruption Crime After the Disbandment of Team of Guards, Government Security and Regional Development (TP4P/D) (study at the Grobogan District Attorney).

\section{Results and Discussion}

\subsection{The effectiveness of performance of Grobogan District Prosecutor's Office in Context of Preventing Criminal Acts Of Corruption}

Corruption is a crime which in quality and quantity continues to increase. The increase in the number of criminal acts of corruption will certainly greatly affect the decline in the quality of welfare for the community. ${ }^{8}$ In order to make the performance of Grobogan District Prosecutor's Office more effective, as the implementation of duties of Guards, Safeguards for Government and Regional Development (TP4D), the Grobogan District Prosecutor's Office remains professional in carrying out its duties in the context of preventing criminal acts of corruption after the dissolution of guard and safeguard team for government and regional development (TP4D), construction of a proper legal system. The abolition of TP4D, which was originally just a discourse, is now final. The decision of Attorney General (Kepja) has been officially issued. With the issuance of Attorney General's Decree no. 345 of 2019 dated 22 November 2019 concerning the

\footnotetext{
4 Mukti Fajar and Yulianto Achmad. (2010). Dualisme Penelitian Hukum Normatif \& Empiris. Yogyakarta: Pustaka Pelajar. p. 34 \& 51.

5 Soerjono Soekanto. (1986). Pengantar Penelitian Hukum. Jakarta: Penerbit Universitas Indonesia. p. 10.

6 Endah Dwi Winarni. Pertanggungjawaban Pidana Dalam Pengelolaan Dana Desa Berdasarkan PP Nomor 8 Tahun 2016 (Studi Kasus Di Desa Srikaton Kecamatan Jaken Kabupaten Pati). Jurnal Daulat Hukum Vol. 1. No. 1 March 2018 ISSN: 2614-560X.

7 Aluysius Sutikna, Sri Kusriyah, Widayati and Kusriyah. Implementasi Undang-Undang Nomor 30 Tahun 2014 Tentang Administrasi Pemerintahan Terhadap Proses Penyidikan Tindak Pidana Korupsi Di Polres Rembang, Jurnal Hukum Khaira Ummah Vol. 13. No. 1 March 2018.

8 Selamet Agista Erikha Bhakti and Djauhari. Upaya Pencegahan Tindak Pidana Korupsi Melalui Peran Serta Masyarakat. Jurnal Hukum Khaira Ummah Vol. 12. No. 2 June 2017. p. 307.
} 
revocation of Attorney General's Decree No. 152/JA/10/2015 regarding the Formation of TP4 Team, then starting in 2020 TP4D has been officially disbanded.

In this study the authors strongly agree in solving the problem of postdissolution of guard and security team for government and regional development (TP4D), so the law system theory from Lawrence M. Friedman will be used. According to Lawrence M. Friedman, the legal system consists of 3 (three) components, namely: ${ }^{9}$

- A component called a structure. It is an institution created by legal systems such as District Courts, Administrative Courts which have the function of supporting the operation of legal system itself. This component of structure allows the provision of services and law enforcement on a regular basis.

- Substantial component, namely in the form of legal norms, both regulations, decrees and so on, all of which are used by law enforcers and those who are regulated.

- Legal components that are cultural. It consists of ideas, attitudes, hopes and opinions about law. This legal culture is distinguished between an internal legal culture, namely the legal culture of lawyers and judgments, and an external legal culture, namely the legal culture of community in general.

These three components determine each other, as well as influence one another. Legal institutions are part of legal structure, in the context of this research what is meant by the legal structure is the Grobogan District Attorney. The Grobogan District Prosecutor's Office as the structure of Attorney General's Office of Republic of Indonesia has an important role in implementing policies for the formation and implementation of duties of Team of Guards, Government Security and Regional Development (TP4D). The successes and failures in implementing policies regarding the formation and implementation of duties of Team of Guards, Safeguards for Government and Regional Development (TP4D) are supported by the ability and competence of Attorney General's apparatus in carrying out their roles.

Based on the research results, the Grobogan District Attorney has formed 3 (three) Teams of Guards, Government Security and Regional Development (TP4D) and the members consist of 6 (six) people per team. The teams formed are tasked with disseminating TP4D and offering assistance for the implementation of regional development using the regional financial budget, so that everything can be on target and there is no deviation in the use of regional finances.

Team of Guards, Government Security and Regional Development (TP4D) at the Grobogan District Prosecutor's Office, this team has conducted outreach to all Regional Government Work Units (SKPD) of Grobogan Regency Government. However, for the implementation of assistance, only a few Regional Work Units (SKPD) at the Grobogan Regency Government asked for assistance for regional development activities, namely: Cleanliness Service, Gardening Service, Agriculture Service, Fishery and Forestry Service, Education Service, Culture and Tourism Service. Grobogan District Food Security and Extension Office. This mentoring

\footnotetext{
${ }^{9}$ Lawrence M. Friedman. (1984). American Law. New York: W.W. Norton and Company. p. 7-12.
} 
collaboration with several Regional Work Units (SKPD) in the Grobogan Regency Government is outlined in the form of a Memorandum of Understanding (MoU). ${ }^{10}$

With regard to the substance of law, the Decree of Attorney General of Republic of Indonesia Number: KEP-152/1/JA/10/2015 concerning the Establishment of Government Guard and Security Team and the Development of Republic of Indonesia Attorney General's Office and the Instruction of Attorney General of Republic of Indonesia Number: INS-001/A/JA/10/2015 concerning the Formation and Implementation of Duties of Government Guard and Security Team and the Central and Regional Development of Public Prosecutor's Office of Republic of Indonesia is a legal substance component. Furthermore, the effectiveness is related to law enforcement, in fact the formation and implementation of duties of Regional Government and Regional Development Guards and Safeguards (TP4D) is a product of legal system whose implementation is highly dependent on the values and beliefs of community and government organizations as part of government that carries out development.

Indeed, the formation of Team of Guards, Safeguards for Government and Regional Development (TP4D) at the Grobogan District Prosecutor's Office has not been able to provide full guarantee or guarantee that in the implementation of regional development there will be no irregularities in regional finance, but at least there have been efforts to minimize leakage and deviations from use regional financial budget and abuse of authority so that it can harm state finances.

For example, in a period of 3 (three) years, starting in 2016, 2017, 2018 and 2019, the Team of Guards, Safeguards for Government and Regional Development (TP4D) at the Grobogan District Prosecutor's Office has handled corruption crimes. One role of Attorney General's Office in optimizing the prevention of criminal acts of corruption through the Regional Government and Development Guard and Security Team (TP4D).

In carrying out its duties and authorities, the Team of Guards, Security for Government and Regional Development (TP4D) still has to coordinate with the Financial and Development Supervisory Agency (BPKP) and the Regional Inspectorate (Itda), so that the position of Team of Guards, Safeguards for Government and Regional Development (TP4D) will not overlaps with the Financial and Development Supervisory Agency (BPKP) and the Regional Inspectorate (Itda), moreover the Regional Guard, Government and Development (TP4D), the Financial and Development Supervisory Agency (BPKP) and the Regional Inspectorate (Itda) have the same goals, namely so that there is no deviation in the implementation of regional development, it can be completed according to the target. Based on the results of this research in the implementation of projects carried out in Grobogan Regency.

\subsection{Constraints and Solutions}

The Grobogan District Prosecutor's Office in the context of preventing criminal acts of corruption after the dissolution of Regional Government and

\footnotetext{
${ }^{10}$ Results of interview with Sri Wishnu Respati, chairman of TP4D Grobogan District Prosecutor's Office
} 
Regional Development Guards and Security Team (TP4D), continues to carry out duties in accordance with applicable laws and the organizational structure of Attorney General's Office, even in reality the effectiveness of law enforcement is technically and juridically still experiencing various obstacles in preventing criminal acts of corruption. The technical obstacles faced after the dissolution of Formation and Implementation of Task of Guard, Government Security and Regional Development (TP4D) Team at the Grobogan District Prosecutor's Office, among others, are as follows: ${ }^{11}$

- There is an opinion from regional officials in the Grobogan Regency Government agency that the Regional Guards, Government Security and Development Team (TP4D) are only looking for mistakes and want to interfere in the implementation of regional development activities. In fact, regional officials from the Grobogan Regency Government's Regional Apparatus Work Unit (SKPD) do not need to be afraid of formation of Regional Government Security, Guard and Development Team (TP4D) by the Grobogan District Prosecutor's Office because TP4D is actually helping the Grobogan Regency Government's Regional Work Unit (SKPD) assistance so that the implementation of development does not experience irregularities or irregularities in the use of regional finances which could qualify as a criminal act of corruption.

- The members of Team of Guards, Safeguards for Government and Regional Development (TP4D) that were formed have not all received training regarding the procedures and mechanisms for the assistance process for Regional Work Units (SKPD). Although not all of members of Team of Guards, Safeguards for Government and Regional Development (TP4D) from the Grobogan District Prosecutor's Office received training regarding the procedures and mechanisms for the mentoring process, in general the objective of formation of this Team of Guards, Safeguards for Government and Regional Development (TP4D) was supervise the development process in the regions where there are indications of irregularities in the use of regional financial budgets.

The solution is: ${ }^{12}$

- Providing understanding to the Regional Government Work Unit (SKPD) of Grobogan Regency Government that law enforcement after the dissolution of Guard, Government Security and Regional Development Team (TP4D) is not to find mistakes in the implementation of regional development activities, but instead provides advice so that irregularities do not occur or fraud in the use of regional financial budgets.

- In carrying out law enforcement duties in a professional manner with the duties and powers of Prosecutor's Office based on Article 30 of Law of Republic of Indonesia Number 16 of 2004 concerning the Public Prosecution Service of Republic of Indonesia, the following are

(1) In the criminal field: Carry out a prosecution; Implementing judges and court decisions that have permanent legal force; To supervise the implementation of conditional criminal decisions, supervisory criminal

11 Results of interviews with Mr. Haryoko Ari Prabowo K Guru Grobogan

12 Results of interviews with Mr. Haryoko Ari Prabowo K Guru Grobogan 
decisions and conditional release decisions; Investigate certain crimes based on law; Completing certain case files and for that reason can carry out additional examinations before being transferred to the Court, which in its implementation is coordinated with the investigator.

(2) In the civil and state administration sector, the prosecutor with special powers can act both inside and outside the court for and on behalf of state or government.

(3) In the field of public order and peace, the prosecutor's office shall participate in carrying out the following activities: Increase public legal awareness; Safeguarding law enforcement policies; Supervision of circulation of printed goods; Control of potentially dangerous beliefs on society and state; Prevention of misuse and/or blasphemy of religion; Research and development of legal and criminal statistics.

\section{Closing}

Based on the research, it is concluded that as the implementation of duties of Guards Team, Government Security and Regional Development (TP4D), the Grobogan District Prosecutor's Office remains professional in carrying out its duties in the context of preventing criminal acts of corruption after the dissolution of team of guards and safeguards for government and regional development (TP4D) in the construction of a legal system that is right. in a period of 3 (three) years, starting in 2016, 2017, 2018 and 2019, the Team of Guards, Safeguards for Government and Regional Development (TP4D) of Grobogan District Prosecutor's Office has handled corruption crimes, showing an achievement from one of roles. The Attorney General's Office in optimizing the prevention of criminal acts of corruption through the Regional Government and Development Guard and Security Team (TP4D).

The obstacles include the following: There is an opinion from regional officials in the Grobogan Regency Government agency that the Team of Guards, Government Security and Regional Development (TP4D) is only looking for mistakes and wants to interfere in the implementation of regional development activities. In fact, regional officials from the Regional Government Work Unit (SKPD) of Grobogan Regency Government do not need to be afraid of formation of Team of Guards, Safeguards for Government and Regional Development (TP4D) by the Pontianak District Attorney because TP4D actually helps the Regional Government Work Unit (SKPD) of Grobogan Regency Government in the form of assistance so that the implementation of development does not experience irregularities or irregularities in the use of regional finances that could qualify as a criminal act of corruption. The solution is as follows: Providing understanding to the Regional Government Work Unit (SKPD) of Grobogan Regency Government that law enforcement after the dissolution of Guard, Government Security and Regional Development Team (TP4D) is not to find mistakes in the implementation of regional development activities, but instead provides advice so that so that there is no deviation or misappropriation in the use of regional financial budgets.

\section{References}




\section{Journals:}

[1] Aluysius Sutikna, Sri Kusriyah, Widayati. Implementasi Undang-Undang Nomor 30 Tahun 2014 Tentang Administrasi Pemerintahan Terhadap Proses Penyidikan Tindak Pidana Korupsi Di Polres Rembang. Jurnal Hukum Khaira Ummah Vol. 13. No. 1 March 2018.

[2] Endah Dwi Winarni. Pertanggungjawaban Pidana Dalam Pengelolaan Dana Desa Berdasarkan PP Nomor 8 Tahun 2016 (Studi Kasus Di Desa Srikaton Kecamatan Jaken Kabupaten Pati). Jurnal Daulat Hukum Vol. 1. No. 1 March 2018 ISSN: 2614-560X.

[3] Much Arif Saiful Anam. Jurnal Pendidikan Agama Islam. Volume 3 Nomor 2, 2015.

[4] Selamet Agista Erikha Bhakti and Djauhari. Upaya Pencegahan Tindak Pidana Korupsi Melalui Peran Serta Masyarakat, Jurnal Hukum Khaira Ummah Vol. 12. No. 2 June 2017.

[5] Lawrence M. Friedman. (1984). American Law. New York: W.W. Norton and Company.

[6] Yosy Budi Santoso and, Umar Ma'ruf. Kebijakan Pembuktian Dan Penuntutan Oleh Jaksa Penuntut Umum Dalam Pemberantasan Tindak Pidana Korupsi. Jurnal Hukum Khaira Ummah Vol. 12. No. 2 June 2017.

\section{Books:}

[1] Mukti Fajar and Yulianto Achmad. (2010). Dualisme Penelitian Hukum Normatif \& Empiris. Yogyakarta: Pustaka Pelajar.

[2] Nyoman Serikat Putra Jaya. (2005). Tindak Pidana Korupsi, Kolusi dan Nepotisme di Indonesia. Semarang: Badan Penerbit Undip.

[3] Soerjono Soekanto. (2007). Metode Penelitian Hukum. Jakarta: UI Press.

[4] Surachmin \& Suhandi Cahaya. (2011). Strategi \& Teknik Korupsi. Jakarta: Sinar Grafika.

\section{Regulations:}

[1] The 1945 Constitution of Republic of Indonesia.

[2] Law of Republic of Indonesia Number 23 of 2014 concerning Regional Government.

[3] Law of Republic of Indonesia Number 31 of 1999 concerning Eradication of Corruption Crime.

[4] Law of Republic of Indonesia Number 20 of 2001 concerning Amendments to Act No. 31 of 1999 concerning Eradication of Corruption Crimes.

[5] Law of Republic of Indonesia Number: 16 of 2004 concerning the Republic of Indonesia Attorney General's Office.

[6] Presidential Instruction Number 7 of 2015 concerning Action to Prevent and Eradicate Corruption in 2015 as an effort to prevent and eradicate criminal acts of corruption.

[7] Decree of the Attorney General of the Republic of Indonesia Number: KEP152/A/JA/10/2015 concerning the Establishment of the Government Guard and Security Team and the Central/Regional Development of the Republic of Indonesia Attorney General's Office. 
[8] Decree of the Attorney General of the Republic of Indonesia Number: KEP135/A/JA/05/2019 concerning Format/Format/Form, Code and Method of Filling in the Intelligence Administration of the Republic of Indonesia Attorney General's Office.

[9] Regulation of the Attorney General of the Republic of Indonesia Number: KEP-014/A/JA/11/2016 concerning Technical Work Mechanisms and Administration of the Government Guard and Security Team and the Development of the Republic of Indonesia Attorney General's Office.

[10] Regulation of the Attorney General of the Republic of Indonesia Number: 04 of 2019 concerning the Intelligence Administration of the Republic of Indonesia Prosecutors' Office.

[11] Instruction of the Attorney General of the Republic of Indonesia Number: INS-001/A/JA/10/2015 concerning the Formation and Implementation of the Duties of the Government Guard and Security Team and the Central and Regional Development of the Republic of Indonesia Prosecutor's Office.

[12] Decree of the Attorney General's Office Number 346 of 2019 on 22 November 2019 concerning the Revocation of the Decree of the Attorney General of the Republic of Indonesia Number: KEP-152/A/JA/10/2015 concerning the Establishment of the Indonesian Attorney General's TP4 as amended by the Decree of the Attorney General of the Republic of Indonesia Number: KEP059/A/JA/03/2018 and Instruction of the Attorney General of the Republic of Indonesia Number 7 of 2019 concerning the implementation of Decree of the Attorney General of the Republic of Indonesia Number 345 of 2019.

[13] Phrase Considering letter $b$ Decree of the Attorney General of the Republic of Indonesia Number: Kep-152/A/JA/10/2015 concerning the Establishment of a Team of Guards and Safeguards for Government and Development of the Republic of Indonesia Attorney General's Office on October 1, 2015. 